<Subscripts >

$1=$ particle 1

$2 \quad=$ particle 2

12 = coagulated particle

\section{Literature cited}

1) Goldman, A. J., R. G. Cox and H. Brenner: Chem. Eng.
Sci., 21, 1151-1170(1966)

2) Horiuchi, T., Y. Kousaka and Y. Endo: Kagaku Kogaku Ronbunsyu, 20, 708-716(1993)

3) Reed, L. D. and F. A. Morrison, Jr.: Int. J. Multiphase Flow, 1, 573-584(1974)

4) Yoshida, T., Y. Kousaka and K. Okuyama: "Aerosol Science for Engineers”, p. 24, Power Co., Tokyo (1979)

\title{
Dispersion Mechanism of Coagulated Particles Consisting of Different Sized Spheres by Acceleration of a Liquid Stream
}

\author{
Takahiro Horiuchi, Yasuo Kousaka \\ and Yoshiyuki Endo
}

Dept. of Chem. Eng., Univ. of Osaka Pref., Sakai 593

\begin{abstract}
Key Words: Coagulated Particle, Aggregate, Breakup, Dispersion, Acceleration, Suspension, Convergent Nozzle

Dispersion of PSL coagulated particles consisting of different sized spheres (1.1 and $1.9 \mu \mathrm{m}$ in diameter) in an accelerating liquid flow field in a convergent nozzle was observed. The experimental results show that the dispersability $D S$, which is defined as the ratio of separation force $F_{d}$ to adhesion force $F_{a}$ between particles and is theoretically obtained, can be a useful measure for the dispersion of coagulated particles in an accelerating flow field.
\end{abstract}

\section{スピルリナ培地中の直線状藻の除去 ${ }^{\dagger}$}

\section{大平勇一・干場正昭* ・小幡英二・安藤公二}

\section{室药工業大学工学部 応用化学科 ${ }^{\dagger+}$}

スピルリナは熱帯地方に自生する藍藻の一種である。 良質の蛋白質やビタミン類を多く含んでいる ${ }^{1,4,5,11)}$ ため, 古来から食料や飼料 ${ }^{10,12,13)}$ として利用されている. 工業 的には日照条件のよい地域において, 大量培養されてい る. また, スピルリナの光合成能を二酸化炭素の固定化 などに応用しつつある ${ }^{3.9)}$. しかし，長期間にわたって培

† 1993 年 9 月 6 日受理; 化学工学会日光大会（日光, 1990 年 7 月）にて一部発表

† $\mathbf{7} 050$ 室蘭市水元町 $27-1$

*三菱鉛筆(株)
養を行うと螺旋状のスピルリナに混じって直線状藻が生 育してくる.この直線状藻とスピルリナの増殖速度, 酸 素発生速度を比較すると両者に差異は認められなかった。 柳本ら ${ }^{13,14)}$ はスピルリナ培地中に存在する直線状藻につ いて検討を行い, Spirulina platensis は培養中にしばし ば崩れた螺旋形を示すとしながらも直線状藻はOscillatoria 属の近縁種とみなしている. Bourrelly ${ }^{2)}$ は Spirulina 属をOscillatoria 属の亜種としており, その違いは

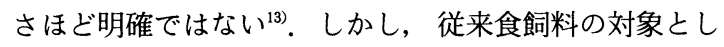
てきた藻体はスピルリナであることから, 直線状藻とス 



(a) The Spirulina culture during the long term artificial cultivation.

(b) Spirulina in the culture reduced $\mathrm{CaCl}_{2}$ concentration $(R=0.32, t=5 \mathrm{~d})$.

(c) Suspended flock of linear algae $(R=0.32, \mathrm{t}=3 \mathrm{~d})$.

(d) Precipitated flock of linear algae $(R=0.32, t=5 \mathrm{~d})$.

Fig. 1 Photographs of the Spirulina culture.

ピルリナの混合培養系から直線状藻を減少させることが 望ましい. スピルリナの単離は, ピペット洗浄法によっ て行われる ${ }^{13)}$. この方法は熟練を必要とし, 大量のスピ ルリナを得るには長期間を要する. そのため, 工業的に 大量培養を行う場合の種母スピルリナを得る方法として, 必ずし屯適しているとはいえない.

著者らは直線状藻の除去を目的として様々な試行を重 ねた。 その結果, 培養液中の $\mathrm{CaCl}_{2}$ 濃度を極端に減少さ せることにより, 直線状藻及びスピルリナの混合培養系 から直線状藻のみを簡単に除去する方法を見いだした。

\section{実験装置及び方法}

本実験に用いた培養液の基本的な組成を Table 1 に 示す (以下, 「 $\mathrm{N}$ 培養液」とする). 種母スピルリナと して $\mathrm{N}$ 培養液に 1 力月毎に植え継ぎ， 5 年間培養した Spirulina platensis を用いた. Fig. 1-a に種母スピル リナの写真を示す.

奏験にル式培養瓶（操作体積 $4 \times 10^{-4} \mathrm{~m}^{3}$ ） を用い, 照度 $45001 \mathrm{x}$, 温度 $303 \mathrm{~K}$, 初発スピルリナ濃度 $0.1 \mathrm{~kg} / \mathrm{m}^{3}$ で一定とした。流量 $3 \times 10^{-6} \mathrm{~m}^{3} / \mathrm{s}$ で通気を行い, 液を 混合した。 $\mathrm{pH}$ を 9.8 に制御するため, 適宜 $\mathrm{CO}_{2}$ を吸収 させた。

サンプリングは定期的に行い, 浮遊物, 沈澌物を採取 しないよう留意した。藻体濃度は波長 $560 \mathrm{~nm}$ の吸光度 から求めた。 また，顕微鏡を用いて直線状藻及びスピル リナを計数し，スピルリナの存在比を算出した。

\section{実験結果と考察}

種母スピルリナの藻体は, Fig. 1-a に示すように, 5 年間の培養でスピルリナのほとんどが直線状藻となっ ている. $\mathrm{N}$ 培養液を用いてスピルリナの培養を行った 場合, スピルリナの存在比（全藻体数に対するスピルリ
Table 1 Composition of the normal medium

\begin{tabular}{lc} 
Compound & Conc. $\left[\mathrm{kg} \cdot \mathrm{m}^{-3}\right]$ \\
\hline $\mathrm{Na}_{2} \mathrm{CO}_{3}$ & 11 \\
$\mathrm{NaHCO}_{3}$ & 10 \\
$\mathrm{NaNO}_{3}$ & 3.0 \\
$\mathrm{Na}_{2} \mathrm{SO}_{4}$ & 2.0 \\
$\mathrm{KCl}$ & 0.5 \\
$\mathrm{~K}_{2} \mathrm{HPO}_{4}$ & 0.5 \\
$\mathrm{MgCl}_{2} \cdot 6 \mathrm{H}_{2} \mathrm{O}$ & 0.4 \\
$\mathrm{CaCl}_{2} \cdot 2 \mathrm{H}_{2} \mathrm{O}$ & 0.05 \\
\hline $\mathrm{Trace}$ minerals & \\
\hline
\end{tabular}

ナ数 $=0.1 \sim 1.0$ ） にほ上んど関係なく, 最大比増殖速 度 $2.6 \mathrm{~d}^{-1}$, 飽和定数 $8.3 \mathrm{klx}$ であった。培養期間中, 存 在比 $X_{S}$ は初発存在比と等しく一定であった.このこと から, $\mathrm{N}$ 培養液で培養を行う場合, 直線状藻とスピル リナの増殖速度は同じであると考えられる, なお, 既報 文の值 ${ }^{3,6,7,8)}$ は最大比増殖速度 $2.0 \sim 3.9 \mathrm{~d}^{-1}$, 飽和定数 $1.5 \sim 10 \mathrm{klx}$ であり, 本実験の值は既報文の值の範囲内 にある。

まず，初発 $\mathrm{CaCl}_{2}$ 濃度を極端に減少させた $\mathrm{N}$ 培養液 に直線増殖期後期の種母スピルリナを植種して培養を 行った. Fig. 2 に藻体濃度 $C_{T}$ 及びスピルリナの存在比 $X_{S}$ の経時変化を示す。なお, 培養中の $\mathrm{CaCl}_{2}$ 濃度を測 定した結果, 初発 $\mathrm{CaCl}_{2}$ 濃度之同じであった。培養液の 初発 $\mathrm{CaCl}_{2}$ 濃度と $\mathrm{N}$ 培養液の初発 $\mathrm{CaCl}_{2}$ 濃度の比 $R$ を $0.16,0.32$ とした場合, 藻体濃度の増加は $\mathrm{N}$ 培養液 $(R$ =1）の場合に比べて小さく, 増殖が抑制された， $R=$ $0.16,0.32$ の場合，スピルリナの存在比は時間の経過と ともに増加し， 6 日目に0.95以上となった（Fig. 1-b）. しかし, $R=0.16$ の場合, 藻体濃度とスピルリナの存在 比の積として試算したスピルリナ濃度 $C_{T} X_{S}$ は 5 日目以 降減少した. $R=0.64$ の場合, 藻体濃度及びスピルリナ 


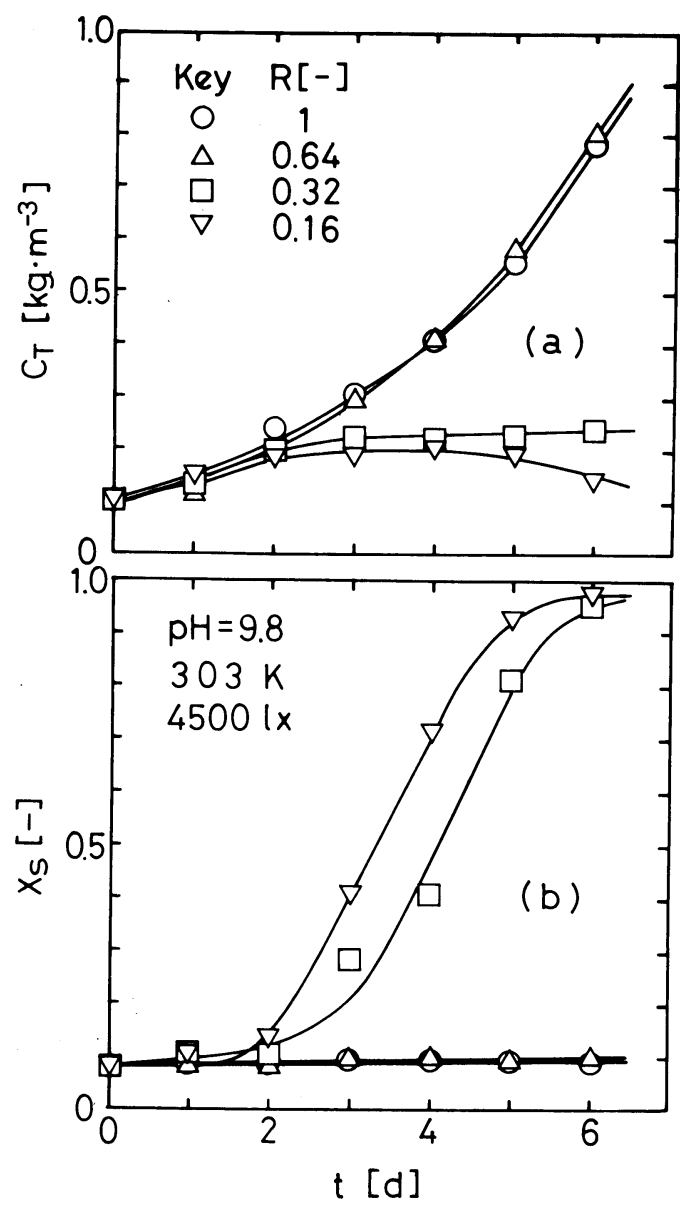

Fig. 2 Time course of total algal concentration $C_{T}$ and the ratio of Spirulina number to total algal numbers $X_{s}$.

の存在比は $R=1$ の場合と同様の挙動を示し, 直線状藻 の除去は行われなかった．このことから, 直線状藻の除 去に適した初発 $\mathrm{CaCl}_{2}$ 濃度比 $R$ は 0.32 であると思われ る.

$R=0.32$ の場合, 培養開始後 3 日目に最大直径 $3 \mathrm{~mm}$ 程度の緑色球状物体が培地中に認められた. 顕微鏡観察 を行った結果, Fig. 1-c のように, 網目状物質（未同 定）により直線状藻が捕捉されており，スピルリナを含 まないことがわかった，直線状藻の凝集体は数を増しな がら徐々に褐変した．褐変した凝集体の顕微鏡写真を Fig. 1-d に示す. 培養開始後 6 日目までに凝集体は培 養瓶内で沈澱し, 培地内に存在する直線状藻が除去され た. $R=0.16$ の場合も同様であった.

次いで, $R=0.32$ で固定し, 直線状藻の除去に及ぼす 種母スピルリナの増殖活性の影響を検討した，直線増殖 期の初期及び中期の種母スピルリナを植種した場合, 直
線状藻は除去されなかった。一方, 定常期の種母スピル リナを植種した場合, 直線状藻が沈澱除去され, Fig. 2, $R=0.32$ とほぼ同じデータが得られた. 上記の培養で得 られたスピルリナを $\mathrm{N}$ 培養液に植種し，培養を行った。 $R=1$ の場合之同様の増殖挙動を示したことから, 増殖 活性が回復していることがわかった.

以上の結果より, 初発 $\mathrm{CaCl}_{2}$ 濃度を $\mathrm{N}$ 培養液の 0.32 倍とし, かつ, 直線增殖期の後期以降の種母スピルリナ を植種した場合, 直線状藻及びスピルリナの混合培養系 から直線状藻を沈澱除去できることがわかった.

[謝辞］本研究を行うにあたり, 故遠藤一夫北海道大学名 誉教授, 本学秋吉亮助教授並びに安居光國講師から有益なご助 言をいただきました，また，実験を行うにあたり，田中靖司， 関口和男, 難波郁子の各氏に協力していただきました。ここに 記して謝意を示します。

$\begin{aligned} \text { Nomenclature } & \\ C_{T}= & \text { total algal concentration } \\ R= & \text { the ratio of initial } \mathrm{CaCl}_{2} \text { concentrations } \\ & \text { in the medium } \\ X_{S}= & \text { the ratio of Spirulina numbers to total } \\ & \text { algal numbers in the Spirulina culture }\end{aligned}$

\section{Literature Cited}

1) Baranowski J. D., C. A. Dominguez and P.C. Magarelli: J. Agric. Food Chem., 32, 1385-1387 (1984)

2) Bourrelly: Les algues diau douce, (Editions N. Boubee \& Cie, Paris), 438 (1970)

3) Clement C., D. Lonchamp, M. Rebeller and H. Van Landeghem: Chem. Eng. Sci., 35, 119-126 (1980)

4) Devi, M. A., G. Subbulakshmi, K. M. Devi and L.V. Venkataraman: J. Agric. Food Chem., 29, 522-525 (1981)

5) Duxbury D. D.: Food Processing, 13, 50-52 (1989)

6) Huang S. and C. Chen: J. Chin. Inst. Eng., 9, 355-363 (1986)

7) Lee H.Y., L.E. Erickson and S.S. Yang: Biotechnol. Bioeng., 29, 832-843 (1987)

8) Ogawa T. and G. Terui: J. Ferment. Technol., 50, 543549 (1972)

9) Ogawa T. and S. Aiba: J. Appl. Chem. Biotechnol., 28, 515-521 (1978)

10) Samson R. and A. LeDuy: Can. J. Chem. Eng., 63, 105112 (1985)

11) Torzillo G., L. Giovannetti, F. Bocci and R. Materassi: Biotech. Bioeng., 26, 1134-1135 (1984)

12) Wu J. F. and W. G. Pond: Bull Environ. Contam. Toxicol., 27, 151-159 (1981)

13) Yanagimoto M. and H. Saitoh: Rept. Natl. FoodRes. Inst., 38, 96-101 (1981)

14) Yanagimoto M. and H. Saitoh: J. Ferment. Technol., 60, 305-310 (1982) 


\title{
Method of Removing Linear Algae from Spirulina Culture
}

\author{
Yuichi Ohira, Masaaki Hoshiba, Eiji Obata and Koji Ando
}

Dept. of Appl. Chem., Muroran Inst. of Tech., Muroran 050

\begin{abstract}
Key Words: Algae, Biochemical Engineering, Food Chemical Engineering, Growth Phase, Medium Composition, Removing, Spirulina platensis

During the long term cultivation, it is known that linear algae grow in or aritificial Spirulina culture. Numerous experiments were carried out to investigate a method of removing linear algae from the Spirulina culture. It was found that linear algae in the Spirulina culture could be removed when inoculated Spirulina were inthe stationary phase or in the later period of linear growth phase if $\mathrm{CaCl}_{2}$ concentration in themedium was reduced by one third from that of a normal medium.
\end{abstract}

* Mitsubishi Pencil Co., Ltd.

\section{エタノールー水系およびメタノールーエタノール系 気液平衡に及ぼす酢酸カリウムの塩効果 ${ }^{\dagger}$}

\author{
松山 清・三島健司・恵谷英之・酒見昌利・長谷昌紀 \\ 福岡大学工学部 化学工学科 ${ }^{+1}$
}

\section{荒井康彦}

\section{九州大学工学部 化学機械工学科}

\section{緒言}

気液平衡に及ぼす塩効果については, 古くから研究さ れているが，有機酸塩を用いた定温系での測定例は少な い。そこで本研究では, 流通型気液平衡測定装置を用い てメタノールー酢酸カリウム系, エ夕ノール-酢酸カリ ウム系および水一䣷酸カリウム系の単一溶媒一塩系の溶媒 の活量デー夕を得た。ささらに，エ夕ノールー水一酢酸カリ ウム系抢よびメタノールーエタノール-酢酸カリウム系の 混合溶媒一塩系の気液平衡を $298.15 \mathrm{~K}$ にて測定し, 塩効 果について検討した。 なお，本測定と同一系（298.15 K）の報告例は見あたらない，また，Chen らのモデル を用いて相関を試みた。

† 1994 年 5 月 10 日受理; 第 29 回化学関連支部合同九州大 会 (福岡, 1992 年 7 月) にて一部発表

†† $\mathbf{7} 814-80$ 福岡市城南区七隈 8-19-1

†十 $\mathrm{T} 812$ 福岡市東区箱崎 6-10-1

\section{1. 実験}

本研究に用いた流通法に基づく測定装置および測定方 法の詳細については，すでに報告してある ${ }^{4,7)}$. 簡単に測 定原理を述べると，溶液を入れたガラス・セル中にキャ リアガス（ヘリウム）を通じ，それぞれの蒸気分圧に比 例するピークをガスクロマトグラフ（TCD 検出器）で 検出する．また，別のセルを用いて同一のピーク高さを 示す純溶媒の温度 $(t)$ を求めると, その温度より分圧 （温度 $t$ における純溶媒の蒸気圧）を決定することがで きる.ただし, 純溶媒の蒸気圧は Antoine 式より決定 しだ)、本実験には，すべて市販特級試薬をそのまま用 いた. メタノール，エタノールおよび無水酶酸カリウム は, 和光純薬工業製で純度はそれぞれ $99.6 \%$ 以上, $99.5 \%$ 以上拉び $99.5 \%$ 以上である. 水にはオルガ, 製のイオン交換水製造装置（MA-3 型）により製造し たイオン交換水を使用した。 なお，酢酸カリウムは水分 